\title{
Universiteit
}

Leiden

The Netherlands

\section{Sing with me, sing, brother, of América}

Fogarty-Valenzuela, B.

\section{Citation}

Fogarty-Valenzuela, B. (2021). Sing with me, sing, brother, of América. Current Anthropology, 62(2), 124-127. doi:10.1086/714045

Version: $\quad$ Publisher's Version

License: $\quad$ Licensed under Article 25fa Copyright Act/Law (Amendment Taverne)

Downloaded from: https://hdl.handle.net/1887/3250567

Note: To cite this publication please use the final published version (if applicable). 


\title{
Sing with Me, Sing, Brother, of América
}

\author{
Benjamin Fogarty-Valenzuela
}

\author{
I climb from the south \\ Toward the entrails of América, \\ The root of a scream \\ Destined to grow \\ And explode. \\ ("Canción con todos," Mercedes Sosa; translation from \\ Spanish by the author)
}

Carlos Javier Ortiz - whose images (figs. 1-6) won the 2021 Current Anthropology Visual Anthropology Prize and appear on this year's journal covers - grew up moving back and forth between Puerto Rico and the US mainland. Echoes of his biography can be seen in the stories he tells through his images: tales of a people's plight for self-determination and democratic government but also sagas of migrants and displaced peoples in search of stability and a place to call home. His photographic works, like his own biography, flow from the interdependence of residents of "América" - a colonial name yet a name still used today to refer to the whole of the continent, South, Central, and North America. In the tradition of much Latin American photography, his works form part of an enduring effort to bear witness to that América - namely, an América characterized by shared histories of colonial rule, of imperial intervention, and of the economic domination of Indigenous peoples.

Like his biography, Ortiz's visual work takes on new relevance at this particular historical conjuncture in the United States. The year 2020 was a "minority white" moment, in which nonwhite racial and ethnic groups under 18 began to make up more than $50 \%$ of the US population, with Latinx people as the second-largest group (http://www.brookings.edu/blog/the-ave nue/2018/03/14/the-us-will-become-minority-white-in-2045-cen sus-projects/). It is also a moment in which more US citizens are engaged in a long-deferred process of reckoning with their nation's history — of resignifying the name America - a process prompted by mass protests and the mainstreaming of right-wing authoritarianism and white supremacy.

When viewed side by side on this year's covers, images from his collections El Sueño, Migrant Workers, and Inherit America reveal more clearly than ever how the history of the United States cannot be understood without understanding the role that Black, Indigenous, and Latinx peoples have played before and since the country's founding. In this way, Ortiz's visual archive can help incorporate the history of America into the history of América. It is an archive that bears witness to the protests, police repression, vigils, and memorials - each depicted on this year's covers - that form part of a people's long-standing fight for collective self-determination.

Ortiz's photographs do more than bear witness. They prompt North American viewers to look into the eyes of long-forgotten brothers and sisters and recognize a shared struggle to restore a shared humanity. In the words of Mercedes Sosa, the legendary singer and steward of Pan-Américan art and music:

All the voices, all!

All the hands, all!

All the blood can be, a song in the wind Sing with me, sing, brother, of América Free your hopes with a cry in the voice.

("Canción con todos," Mercedes Sosa; translation from Spanish by the author)

Benjamin Fogarty-Valenzuela is a Mansueto Fellow and Postdoctoral Scholar at the University of Chicago (1126 East 59th Street, Chicago, Illinois 60637, USA [benjaminfv@uchicago.edu]). This paper was submitted 12 II 21, accepted 17 II 21, and electronically published 31 III 21. 


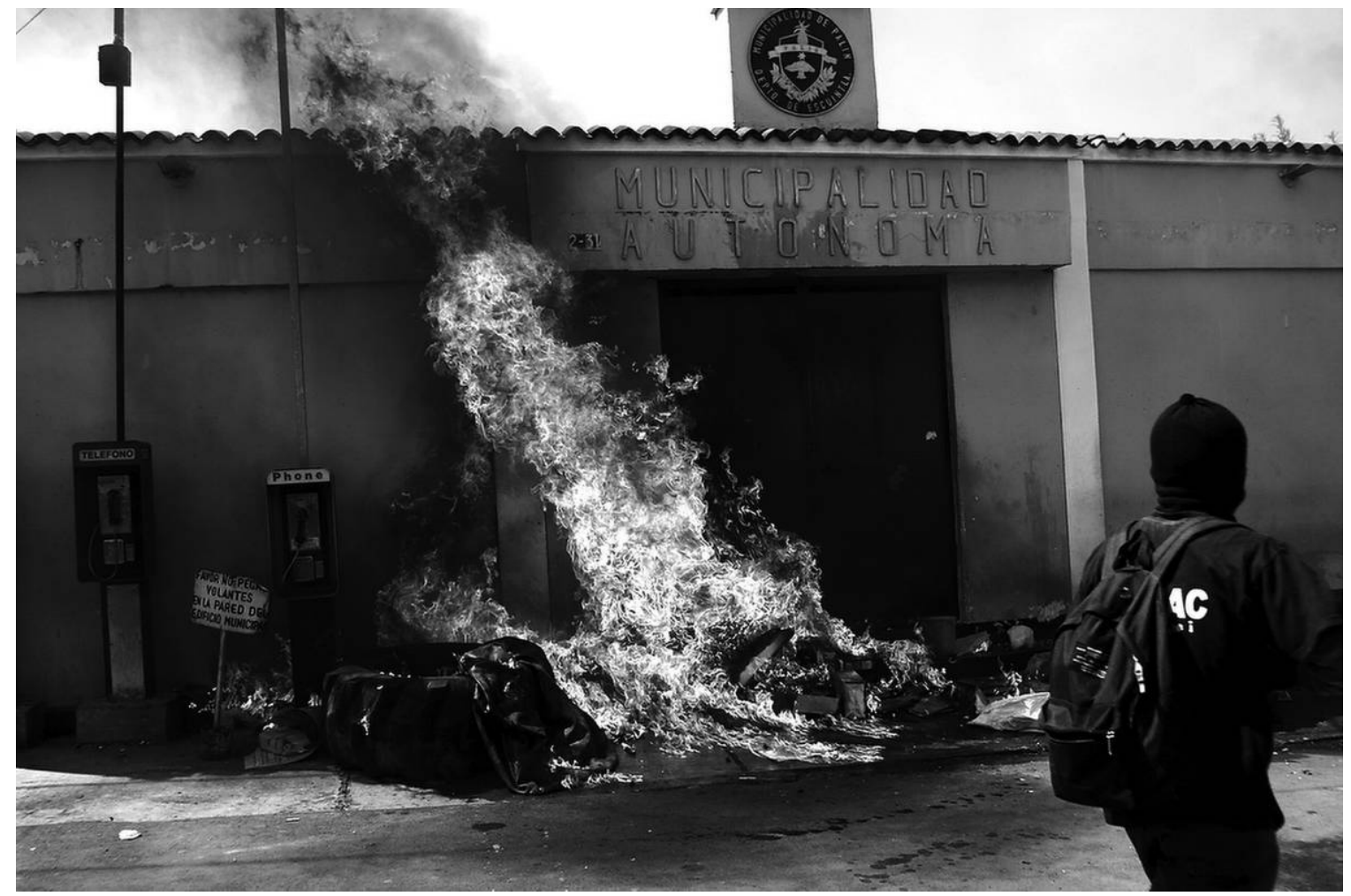

Figure 1. Protesters in Palin, setting fire to the mayor's office. Hundreds of residents took to the streets to demonstrate against what they say is evidence of voter fraud during mayoral elections. Photo by Carlos Javier Ortiz. September 11, 2007.

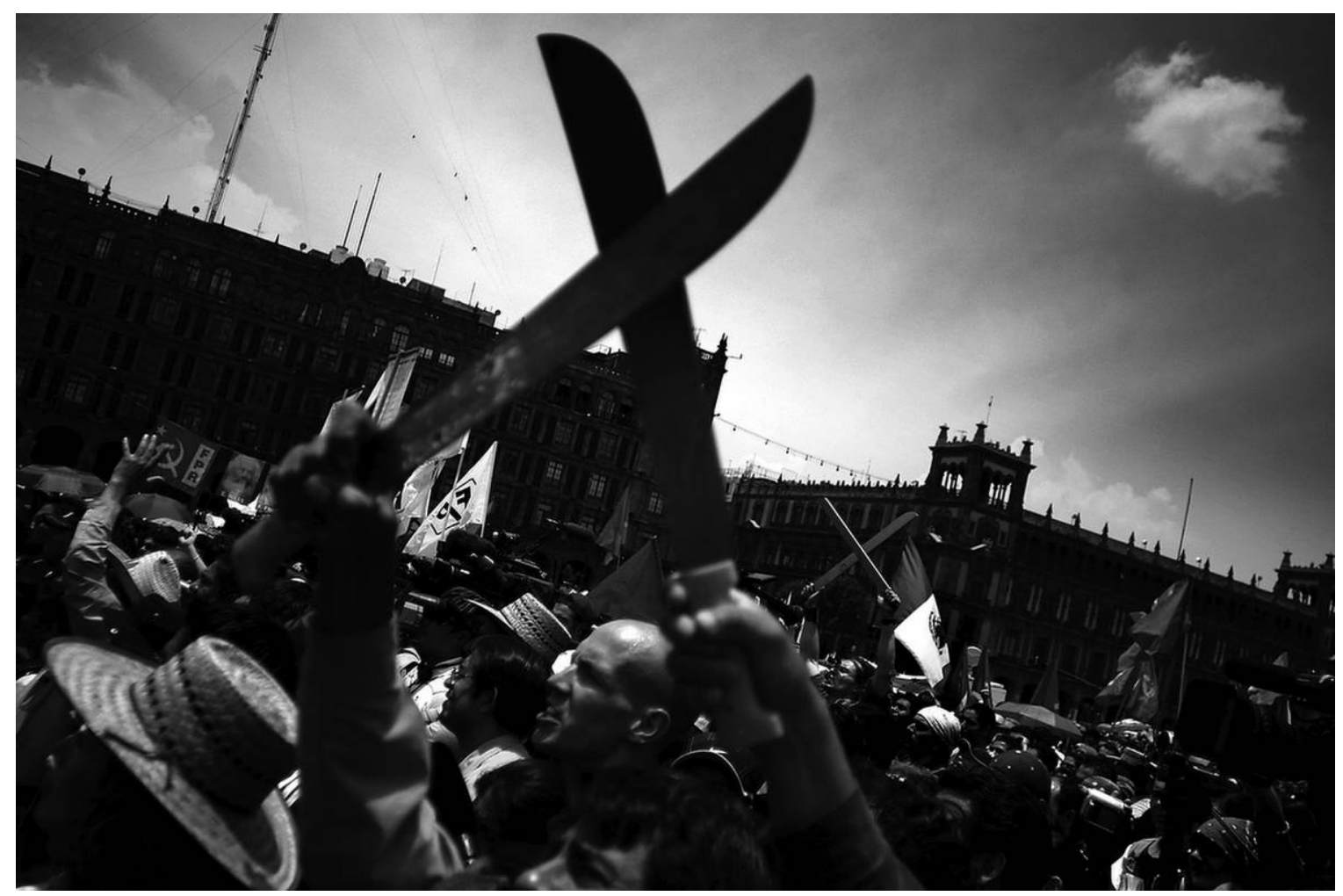

Figure 2. Thousands of protesters marched on election day, July 7, 2006, led by Zapatista rebel leader Sub Comandante Marcos. They demanded justice for human rights abuses and to criticize the current political system. Photo by Carlos Javier Ortiz. July 7, 2006. 


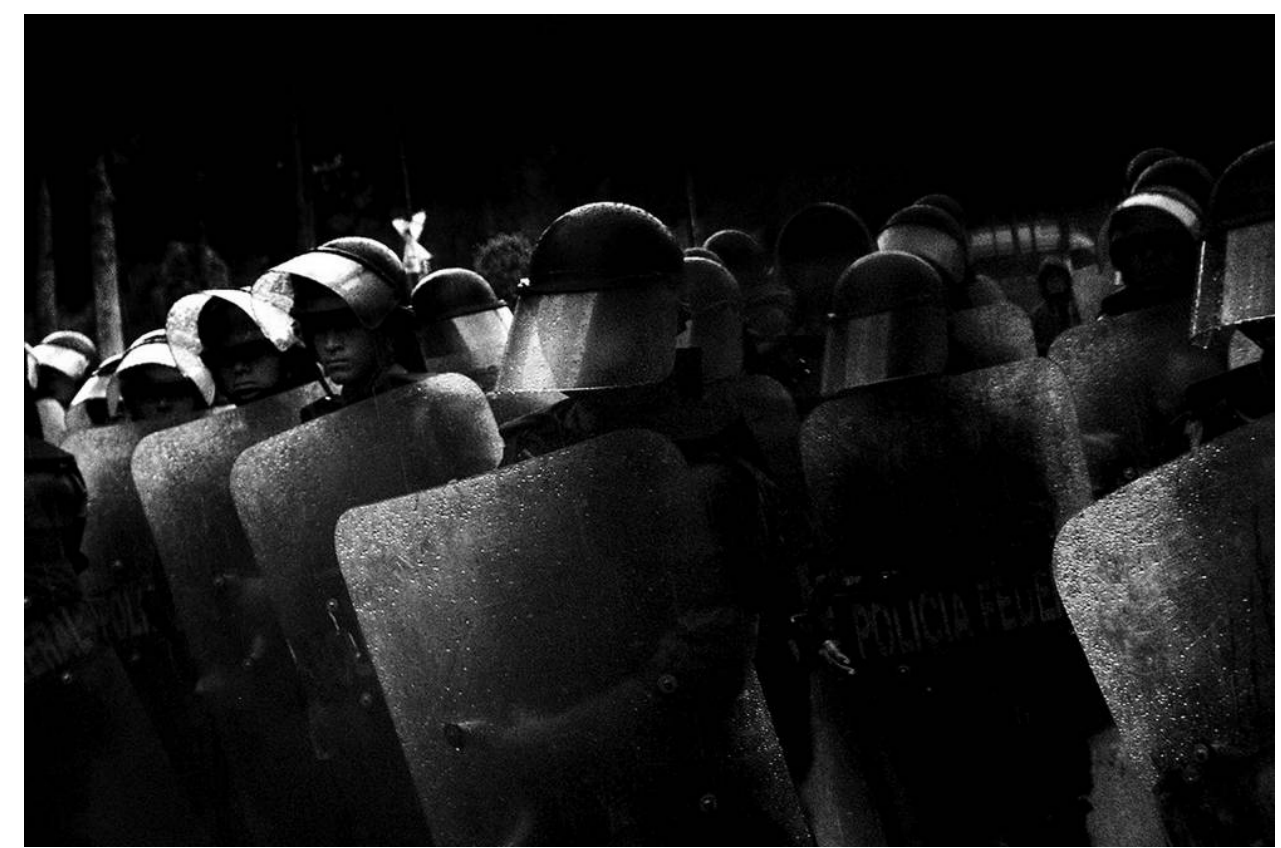

Figure 3. Riot police guard themselves against protesters who throw rocks over a barrier fence near the Union Congress Friday, September 1, 2006, in Mexico City before the annual state-of-the-nation speech by outgoing President Vicente Fox. Photo by Carlos Javier Ortiz. September 1, 2006.

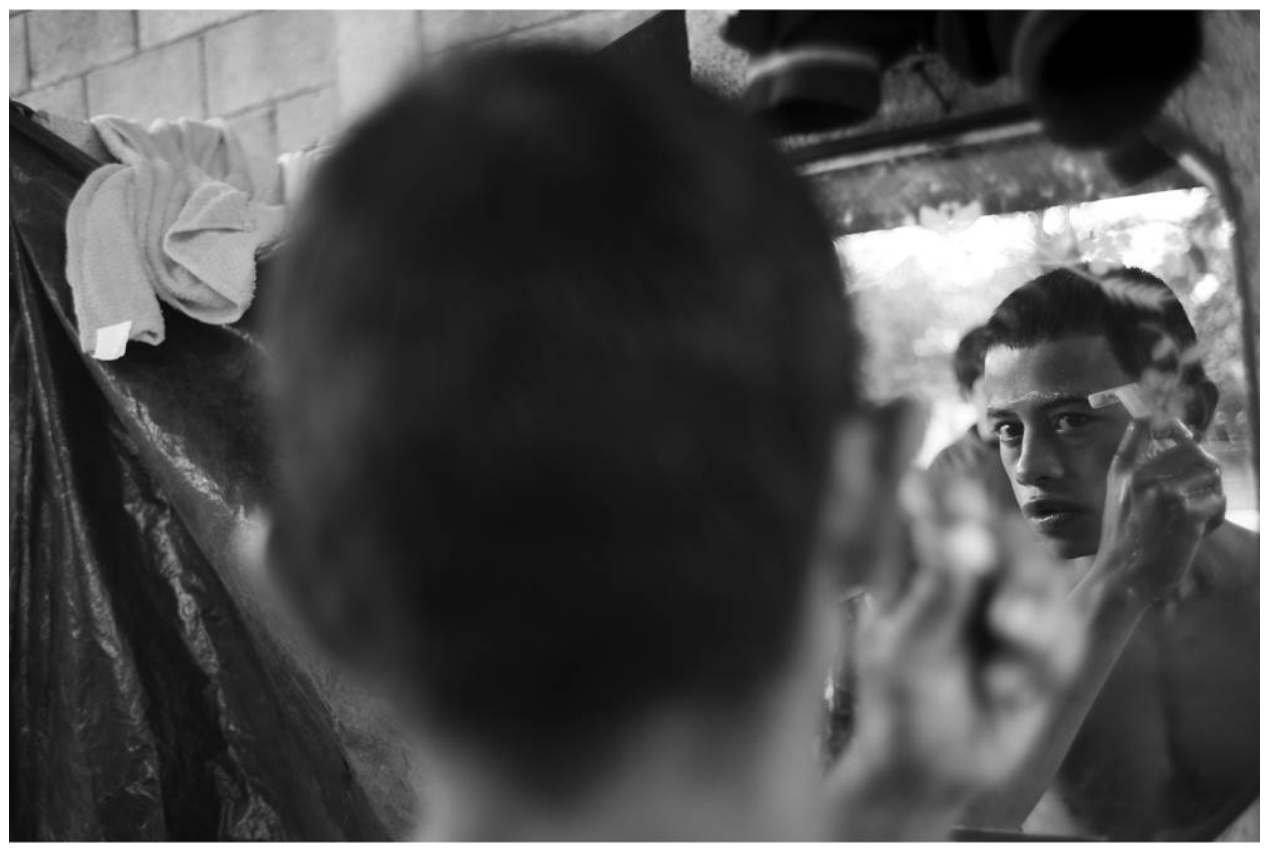

Figure 4. During the 36 years of Guatemalan civil war, more than 200,000 people had died before the government and leftist rebels made peace in 1996. Since then Guatemala has been rocked by violent drug traffickers and street gangs. With almost 6,000 Guatemalans slain last year, nearly the same number that occurred in a single year of the civil war, the Guatemalan murder rate is one of the highest in the world. The violence Guatemalans faced in their post-civil war lives drove many of them to flee the country in search of a better life. During the past 10 years, thousands of Guatemalans have migrated north, some to Mexico and many more to the United States, to find jobs, stability, and a peaceful existence. Unfortunately, many of them found their way to neighborhoods plagued by violence, poverty, and crime. Guatemala is not the only country facing this problem. Guatemala's neighbor to the north, Mexico, faces similar crises. Many Mexicans are drawn to the United States to escape poverty and lack of opportunity in their own country. These images document Guatemalans in their countries. Their journeys are filled with hope, desperation, and, most importantly, humanity. Photo by Carlos Javier Ortiz. August 2006. 


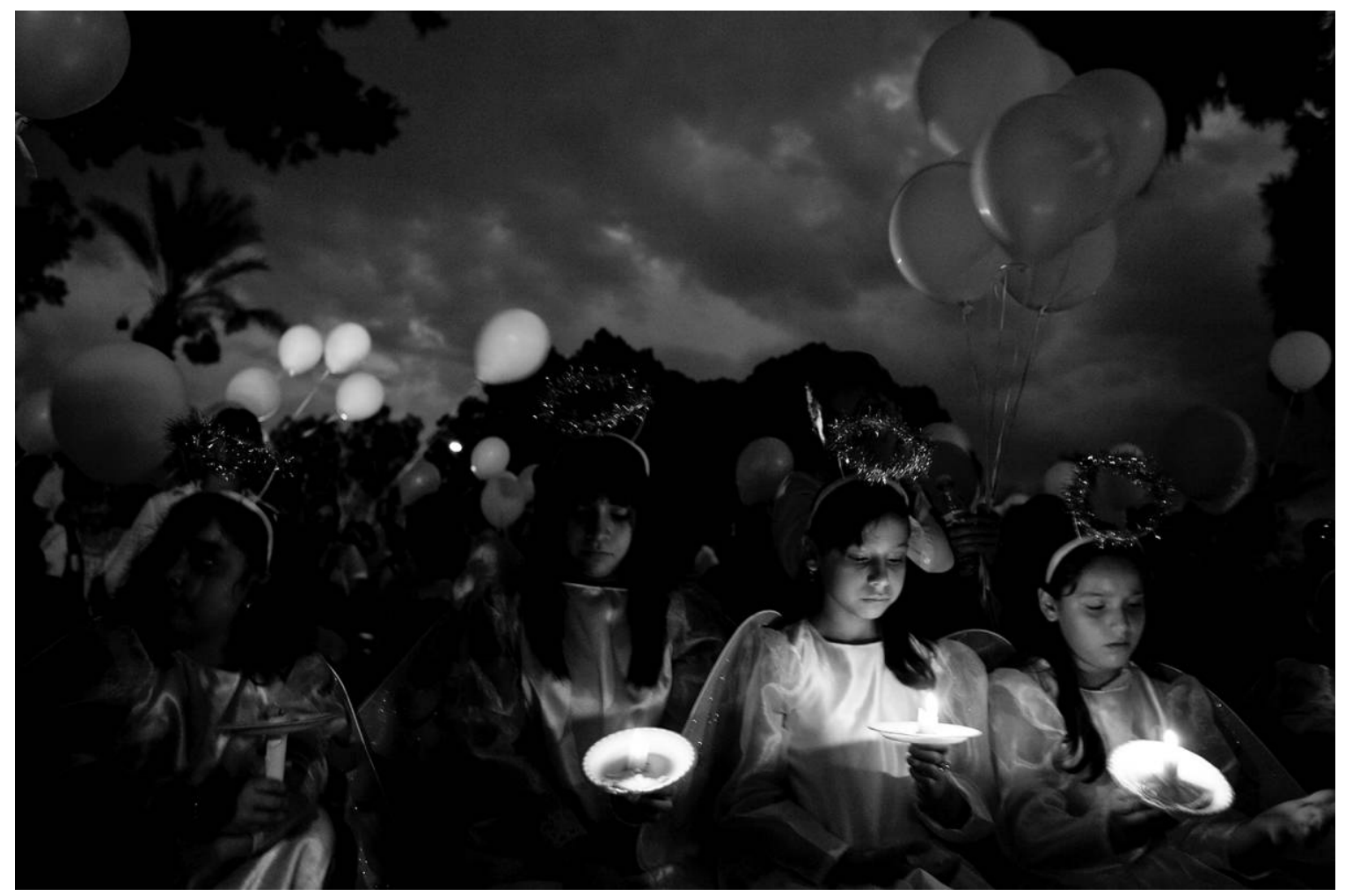

Figure 5. People against Senate Bill 1070 legislation celebrate in Phoenix, Arizona, on July 28, 2010, outside the state capitol building after Judge Susan Bolton came out with a decision blocking some of the most controversial parts of Arizona's SB 1070. The state's controversial law was slated to go into effect on July 29. Photo by Carlos Javier Ortiz. July 2010.

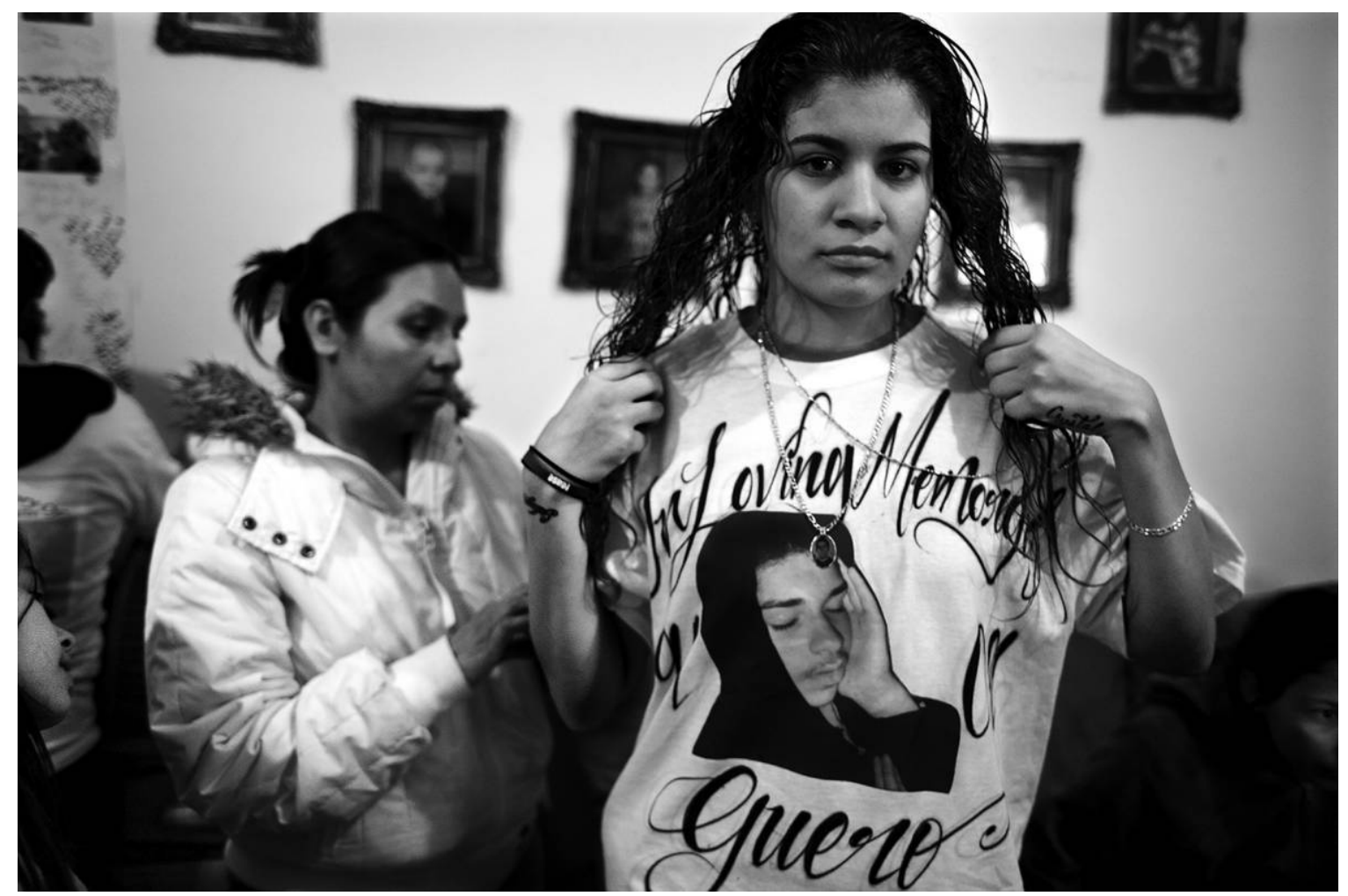

Figure 6. A girl shows off a T-shirt in memory of her 14-year-old cousin, Juan Cazares, days after he was murdered. New City, Chicago, 2009. Photo by Carlos Javier Ortiz. March 2009. 